\title{
Prudential Regulations and Financial Performance of Commercial Banks in Kenya
}

\author{
Keston Enock Kiplagat \\ Egerton University \\ Dr. Fredrick Kalui (PhD) \\ Egerton University,P.o.Box 536,Egerton
}

\begin{abstract}
Prudential regulation forms a critical part of operations in the banking sector. The aim of the regulations is to protect investors and consumers and ensure systemic stability. Consequently, commercial banks are required to maintain adequate level of capital, liquidity, asset quality, credit risk and management efficiency. In Kenya, the CBK implemented the prudential regulations in 2013. However, there is no consensus from existing studies whether the new regulations have a positive or negative influence on bank performance. The main objective of this study was to determine the effect of prudential regulations on the financial performance of commercial banks in Kenya. The sample comprised of all 43 commercial banks operating in Kenya observed over the study period, 2013-2017.Data was extracted from annual financial reports of the banks and Central bank of Kenya (CBK) annual regulatory reports, which reduced the sample to 36 banks. The study adopted correlation research design and examined the relationship between the independent variables and performance. Multiple regression model was used to determine the linear relationship to examine the effect of the prudential regulations of profitability of commercial banks. From study findings, liquidity management, credit risk management and management efficiency has significant effect on the financial performance of commercial banks while capital adequacy and asset quality has no significant effect on the performance of commercial banks in Kenya. The research findings are useful to the CBK and banks, as it demonstrates the extent to which new prudential regulations influence the financial performance. Variables contributing positively to financial performance should be strengthened while those influencing performance negatively should be reviewed. This will enable the formulation of policies and strategies that will help in running the operations of commercial banks. The investment advisors and analysts use the research outcome to advise their clients on the future prospects and sustainability of investments in commercial banks. The study recommends adoption of the regulation as it affects banks financial performance thus improve banks stability and reduces chances of insolvency.
\end{abstract}

Keywords: liquidity and credit risk management, management efficiency, capital adequacy and asset quality, financial performance

DOI: $10.7176 /$ RJFA/11-14-06

Publication date:July $31^{\text {st }} 2020$

\section{Background of the study}

The special role that banks play in the economic system implies that banks should be regulated and supervised not only to protect investors and depositors but also to ensure systemic stability (Sentero 2013). Regulation refers to a process of monitoring financial institutions by an authority that is established by the government in an effort to achieve macroeconomic goals through monetary policies. Regulation subjects financial institutions to certain requirements, restrictions and guidelines, aimed at maintaining stability and growth of the financial systems in a country (Eden, 2014).

The global banking crises has made the need for regulatory and supervision framework in the financial sector a priority for economic stability. Regulation for the banking sector started at international level with the 1988 Capital Accord (Basel I), which was later revised in the new capital adequacy framework (Basel II) (Pasiouras et al., 2009). Basel I became the first globally accepted standard, setting the minimum capital ratio to help account for risk-weighted assets and off-balances sheet exposures. Basel II upgraded on the two requirements by creating supervision by central authorities as well as establishing market discipline (Beltratti \& Stulz, 2012).

Consequently, countries have continuously upgraded their bank regulation and supervision approaches to focus on financial regulations that involve liquidity management, capital adequacy, asset quality, credit risk management and management efficiency. However, there is no consensus on whether prudential regulations influence performance positively. For instance, Alemayehu and Ndungu (2012) argues that, poor liquidity management and capital inadequacy affects earnings and in some cases causes insolvency. However, Mwongeli, (2006) argued that there is no significant relationship between prudential regulation and bank performance.

In Kenya, CBK issued prudential regulations for banks that came to effect on $1^{\text {st }}$ January 2013. These regulations were aimed at protecting customer's deposits and manage systemic risks and consequently have a positive impact on the banking sector financial performance (Mabeya et al., 2016). However, some recent problems 
in the banking sector have been attributed largely to poor liquidity, capital adequacy, asset quality, credit risk management and management efficiency. For instance, the Central Bank of Kenya placed Dubai Bank Kenya in 2015 under receivership following what it termed as serious liquidity challenges and capital deficiencies. The Chase Bank was also put under statutory management for a year in April, 2016 due to what the regulator termed as liquidity difficulties (Kipruto et al., 2017).

\section{Statement of the problem}

The special role that banks play in fostering economic growth implies that banks should be regulated and supervised not only to protect investors but also to ensure systemic stability. Consequently, prudential regulations require banks to maintain adequate levels of capital, liquidity, credit risk, asset quality, and management efficiency requirements. However, the challenges facing the banking industry to date are associated with liquidity management, capital inadequacy, non-performing loans, credit risk management and management efficiency which have led to liquidation and collapse of some banks. The CBK issued prudential regulations for banks that came to effect on $1^{\text {st }}$ January 2013 aimed at protecting customer's deposits, investments and manage systemic risks.

The impact of prudential regulations on bank performance is widely studied in Kenya. However, the existing empirical studies depict inconsistencies and knowledge gaps. Some studies show that prudential regulations positively impact on bank performance (Guthua, 2013; Odongo, 2013; Sentero, 2013; Majakusi, 2016). However, Nyanga, (2012) found a negative correlation between prudential regulations and bank's financial performance. The study addressed the knowledge gaps by examining how prudential regulations affect the performance of banks. This study was also different from others as existing studies are based on older prudential regulation (Odongo, 2013; Nzioki, 2011; Njuele, 2013). This study is based on the latest prudential regulation, 2013.

\section{General objective}

The general objective of the study was to determine the effect of prudential regulations on the financial performance of commercial banks in Kenya.

\section{Specific objectives}

The specific objectives from the general study included:

i). Capital adequacy regulation has a significant effect on the financial performance of commercial banks in Kenya. ii). Liquidity management regulation has a significant effect on the financial performance of commercial banks in Kenya.

iii). Asset quality regulation has a significant effect on the financial performance of commercial banks in Kenya. iv). Credit risk management regulation has a significant effect on the financial performance of commercial banks in Kenya.

v). Management efficiency regulation has a significant effect on the financial performance of commercial banks in Kenya.

\subsection{Research Hypotheses}

The main hypotheses tested in the study, namely:

$\mathrm{H}_{01}$ Capital adequacy regulation has no significant effect on financial performance of commercial banks.

$\mathrm{H}_{02}$ : Liquidity management regulation has no significant effect on financial performance of commercial banks.

$\mathrm{H}_{03}$ : Asset quality regulation has no significant effect on financial performance of commercial banks.

$\mathrm{H}_{04}$ : Credit risk management regulation has no significant effect on financial performance of commercial banks.

$\mathrm{H}_{05}$ : Management efficiency regulation has no significant effect on financial performance of commercial banks.

\section{Literature Review \\ Theoretical Framework \\ Liquidity Management Preference Theory}

The theory was put forward by John M. Keynes (1939). The theory asserts that institution hold funds to meet obligations as they fall due without incurring unacceptable losses. Liquidity preference refers to the amount of money the public is willing to hold given the prevailing interest rate. Liquidity refers to the ability of an institution to fund increase in assets and meet obligations as they fall due without incurring unacceptable losses or risking damage to the banks reputation (Guthua, 2013). Liquidity risk emerges when market players are unable to convert their stocks into cash when required. This may be due to infrastructure inefficiencies and general market tightness (The Kenya Financial Sector Stability Report, 2014). Keynes argued that there are three reasons for holding liquid assets; for transactions purposes, precaution against a contingency and for speculative purposes.

Commercial banks face various risks that may affect their performance; liquidity risk is the risk that a bank will encounter difficulty in meeting obligations from its financial liabilities. The aim of managing liquidity is to ensure, that banks have sufficient liquidity to meet its liabilities when due, banks are required to maintains a 
portfolio of short-term liquid assets, largely made up of short-term liquid investment securities, loans and advances to banks and other inter-bank facilities, to ensure that sufficient liquidity is maintained thus increase its performance (Njeule, 2013).The theory therefore is applied in the study to determine the effects of liquidity management on financial performance of commercial banks in Kenya.

\section{The Capital Buffer Theory}

The capital buffer theory was advanced by Marcus (1984). The theory asserts that Banks may prefer to hold a buffer of excess capital to reduce the probability of falling under the legal capital requirements. Capital buffer is the excess capital a bank holds above the minimum capital required. The theory explains that banks with low capital buffers attempt to rebuild an appropriate capital buffer by raising capital and banks with high capital buffers attempt to maintain their capital buffer. A breach of the capital requirements is considered a major infringement of banking legislation and is not tolerated by the Central Bank. Banks remaining undercapitalized for prolonged periods are closed (Kipruto et al., 2017).

The capital buffer theory contends that ability of banks to mobilize enough deposits prevents the capital base from being eroded. According to theory, more capital tends to absorb adverse shocks and thus reduces the likelihood of failure and therefore increases its performance (Calem \& Rob, 1996). In line with the capital buffer theory, banks aim at holding more capital above the regulatory minimum as insurance against breach of the regulatory minimum capital requirement. Consequently capital adequacy regulations are assumed to be positively related to bank financial performance (Sentero, 2013). The theory therefore is applied in the study to determine the effects of capital adequacy regulation on financial performance of commercial banks in Kenya.

\section{Financial performance}

Financial performance is a measure of how well a bank is utilizing its resources to generate income. Bank's financial performance is not only important to bank management and shareholders but also to customers and creditors as they make decisions on dealing with the bank (Ndolo, 2017). Commercial banks operate with the objective of making profits. Profits ensure continuity of business taking into account the current competition within the banking industry, this goal can either be enhanced or curtailed by the prudential regulations (Gudmundson et al., 2013).

There are various ratios to measure profitability of banks such as ROA and ROE. ROA ratio indicates profitability of banks by comparing income to total assets, which is a better measure of performance as it includes even borrowed capital. ROE indicate what shareholders get in return for their investment by showing how much profits a company has earned compared to the total amount of shareholders equity The higher the ratio, the better the level of performance as it indicates effectiveness in the use of shareholder's equity while the lower the ratio, the poor the performance and indicate inefficiency in the use of shareholder's equity. The study measured performance using ROA since it's the most commonly used performance indicator. The Return on Assets (ROA) is a profitability measure that evaluates profitability based on the efficiency that a firm utilizes assets to generate profits

Bank performance can be influenced by both internal and external factors. The internal factors are the individual banks characteristics influenced by decisions made by the individual bank management and governing board. External factors are issues that are beyond control of individual banks, inflation, interest rates and political instabilities of a country (Ongore and Kusa, 2013). In commercial banks, good performance results in increased profitability and shareholders worthiness. A profitable bank increases its shareholders worthiness thus maximization of wealth is achieved (Njeule, 2013). Commercial banks play a major role in the economy of resources allocation in Kenya, they channel funds from depositors to investors. This can only be done is the banks are profitable. Good financial performance rewards shareholders for their investment thus encourage additional funding resulting in economic growth. Poor performance by the banks can result in banking failure than can have a negative impact on the economy of a country (Ongore and Kusa, 2013).

\section{Commercial Banks in Kenya}

A commercial bank is a financial institution that accepts deposits and offers loans. Commercial banks in Kenya are licensed and regulated pursuant to the provision of the Banking Act and prudential regulation in place. The licensing and regulation is done by the Central bank, whose mandate is to protect depositors and manage systemic risks affecting the sector thus stabilize the banking sector. The government of Kenya acknowledges that commercial banks play a key role to the economy in terms of job creation, poverty eradication and fostering economic growth (Njeule, 2013).

Kenya's financial sector has grown significantly in size and complexity as it continues to support the overall economy and contribution to overall Gross Domestic Product (GDP)Banks have diversified their products and services such as, loans, debit and credit cards, electronic banking, mobile banking, agency banking and automated teller machines due to the stiff competition within and outside the sector (Masinde, 2017).The banking industry`s 
overall capital adequacy ratio averaged 19 per cent against a statutory minimum of 14.5 per cent with average liquidity ratio of 38.3 per cent as at end December 2015. Liquidity was, however, skewed in favour of large tier banks. However, the banking subsector faced liquidity risks coupled with skewed distribution and corporate governance issues (Mwega, 2014).

As of 2013, there were forty three licensed commercial banks operating in Kenya that are licensed and regulated by the Banking Act and Prudential regulation issued under by the Central bank of Kenya. They are the dominant players in the Kenyan Banking system and closer attention is paid to them while conducting off-site and on-site surveillance to ensure that they are in compliance with the laws and regulations. Most of the Commercial banks are located in Kenya's major towns and have branches across the country (Ali, 2015).

The banking sector has undergone many regulatory reforms in the past decade. The reforms have brought about a lot of changes in the way banks operate and have significantly strengthened the sector. Commercial banks dominate the financial sector in Kenya as they bridge the gap between the supply and demand for money in the economy. The central bank of Kenya has classified commercial banks depending on their asset base. Tier I banks are the large banks whose asset base is above fifteen billion shillings. Tier II are the medium banks whose asset base is above five billion shillings while the tier III banks are the small banks whose asset base is below five billion shillings (Nzoka, 2015)

\section{Prudential Regulations}

The study considered five regulations which includes Capital Adequacy Regulation, Liquidity Management Regulation, Asset Quality Regulation, Credit Risk Management, and Management Efficiency

\section{Capital Adequacy Regulation}

Capital adequacy refers to a relative measure that establishes the maximum level of leverage that financial institutions are allowed to reach on its operations (Jansen, 1997). This prudential regulation is issued under section 18 of the Banking Act, which empowers central bank to prescribe the minimum ratios being maintained by banks between their core capital and total capital. The regulation aims at ensuring that banks maintain capital level that is adequate to protect depositors and creditors, commensurate with the risks associated with activities and profile of the bank thus promote public confidence.

Capital adequacy protects a bank against credit, market and operational risks so that it can absorb any losses that may arise and protect debtors (Kipruto et al., 2017). The capital adequacy ratio shows the internal strength of a bank to withstand losses during crisis. Bank's capital management is also aimed at supporting its business and to maximize shareholders' value and enhance profitability (Ongore and Kusa, 2013). The adequacy of capital is judged based on capital adequacy ratios. This is measured by the ratio of bank's capital expressed as a percentage of risk weighted assets (Sentero, 2013; Dang 2011).

\section{Liquidity Management Regulation}

Liquidity refers to the ability of an institution to fund increase in assets and meet obligations as they fall due without incurring unacceptable losses or risking damage to the banks reputation. (Guthua, 2013). Banks maintains a portfolio of short-term liquid assets, largely made up of short-term liquid investment securities, loans and advances to banks and other inter-bank facilities, to ensure that sufficient liquidity is maintained. The level of liquidity of a bank is measured by the ratio of total loans to customer deposits or customer deposits to assets ratio (Mwongeli, 2013). This study measured liquidity by using customer deposits to assets ratio since it's the most used ratio by banks.

\section{Asset Quality Regulation}

The asset quality of a bank is defined by its credit portfolio, fixed and current assets and other investments (Athanasoglou et al., 2005). Loans are a major asset that generates the major share of banks income. The quality of a loan portfolio determines the profitability of banks as losses from non-performing loans pose a big risk to banks. The objective of asset quality is to ensure that nonperforming loans in banks is as low as possible thus reduce chances of bank losses. Asset quality is a ratio of nonperforming loans to total loans (Ongore \& Kusa, 2013). It is also measured by the ratio of gross Loans to Net Assets (CBK, 2013). This study measured asset quality using nonperforming loans to total loans ratio because it's the commonly used ratio by the banks.

\section{Credit Risk Management}

Credit risk management refers to as a set of financial activities that maximizes the performance of a bank by reducing costs associated with the cash flow volatility. A bank's behavior toward risk affects the choice of risk management activities. A bank's robust risk management framework can help reduce exposure to risks, and enhance their performance. (Wanjohi et al.,2017). Financial risk management is one of the most important functions in banking industry as commercial banks are faced with risks such as credit risk, liquidity risk, foreign 
exchange risk, market risk and interest rate risk, among others. CBK assesses the risk exposed to each bank and suggests effective procedures to identify, measure, monitor and control of the risk. (Anguka, 2012). The study analyzed credit risk as it's the most common type of risk as banks offer loans. It's a ratio of non-performing loan to total assets.

\section{Management Efficiency}

Management Efficiency is one of the key internal factors that determine the bank profitability. It is represented by different financial ratios like total asset growth, loan growth rate and earnings growth rate. The capability of the management to deploy its resources efficiently, income maximization, reducing operating costs can be measured by financial ratios. The study adopted total operating expenses to total revenue ratio in calculating management efficiency. (Ongore \& Kusa, 2013)

\section{Conceptual Framework}

The conceptual framework provides the scheme that relates the variables used to investigate the subject of interest. It provides the association between dependent variable and the independent variables. The performance of commercial banks may improve as capital adequacy protects a bank against credit, market and operational risks so that it can absorb any losses that may arise and protects debtors. Adequate level of capital is therefore expected to positively influence bank performance. The intervening variable of bank ownership is crucial as different owners have different interests and capacities to influence performance.

Figure 1: Conceptual Framework

Independent Variables

\begin{tabular}{|l|}
\hline Capital adequacy \\
\hline Liquidity management \\
\hline Asset quality \\
\hline Credit risk management \\
\hline Management efficiency \\
\end{tabular}

\section{Dependent Variable}

Intervening variable

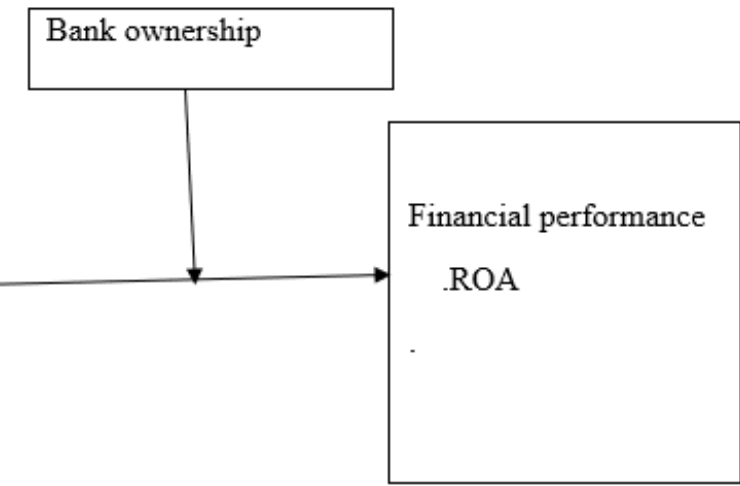

\section{Research Methodology}

Target Population.

The target population comprise of all the commercial banks licensed to operate in Kenya over the period of study, 2013-2017. The period is selected as it represents the period immediately after the enactment and implementation of prudential regulations. A period of five years after the implementation of the prudential regulation is selected for analysis as it allows for the new regulation to affect the performance of banks.

All commercial banks operating in Kenya were analyzed in this study hence the study adopted census survey method. This is occasioned by the fact that population of commercial banks operating in Kenya banking sector is small. As of 2013, there were only 43 licensed banks, which justified complete enumeration of all banks. The study population comprised of all the forty-three commercial banks that operated in Kenya during the period of study. Banks with data gaps were eliminated, seven banks were eliminated thus only thirty six (36) banks were analyzed. The banks that were eliminated are; charterhouse bank limited, chase bank Kenya limited, Dubai bank Kenya limited, Fidelity commercial bank limited, Giro commercial bank limited, Habib bank limited and Imperial bank

The study adopted a correlational research design. The design allows researcher to analyze inter-relationship among many variables in a single study. It also allows a researcher to analyze several variables either individually or in a combination that might affect a particular phenomenon being studied (Kipruto et al., 2017). This research 
design is appropriate for a study that seeks to examine relationship between variables, which is the objective of the study.

The study used secondary data. Secondary data was appropriate for the study since the financial performances of firms are published by firms in annual financial reports. The study collected data from annual financial reports (company financial statements) from all the banks and CBK annual supervisor's reports for five years after prudential regulation implementation date. The variables for the five-year period (2013 -2017) were computed as indicated below. The data collected were ratios, which are arbitrary values that indicate the relationship between the derivatives. These ratios are the capital adequate ratios, asset quality ratio, liquidity ratio, efficiency ratio and credit risk ratio, with the derivatives captured in the data collection sheet.

The secondary data collected was analyzed by the use of inferential and descriptive statistics using SPSS. Descriptive statistics explains the attributes on the data collected and analyzed. The descriptive statistics used included minimum, maximum, mean and standard deviation and presented in the form of tables and trend analysis. Inferential statistical techniques were used to test study hypotheses at $5 \%$ significance level. Correlation coefficient measure was used to establish the strength of relationship between the variables. Multiple regression model was used to analyze the influence of independent variables on dependent variables. The following regression model was adopted;

$\mathrm{Y}=\mathrm{a}+\beta_{1} \mathrm{X}_{1}+\beta_{2} \mathrm{X}_{2}+\beta_{3} \mathrm{X}_{3}+\beta_{4} \mathrm{X}_{4}+\beta_{5} \mathrm{X}_{5}+\varepsilon$

Where

$\mathbf{Y}=$ Financial Performance measured by return on assets (ROA)

$\boldsymbol{X}_{I}=$ Capital Adequacy measured by capital adequacy ratio (CAR) which is a measure of how much equity a bank holds to protect the investors from possible insolvency. CAR is computed as the quotient of shareholder's capital to risk weighted assets (RWA).

$\mathbf{X}_{2}=$ Liquidity Management measured by liquidity ratio which captures bank's ability to handle short-term obligations, computed as the ratio between total customer deposits and total assets

$\mathbf{X}_{\mathbf{3}}=$ Asset Quality is measured using the asset quality ratio (AQR), which is a measure of the performance of issued loans

$\mathbf{X}_{4}=$ Management efficiency given by Total operating expenses to total Revenue

$\mathbf{X}_{\mathbf{5}}=$ Credit Risk management measured by Credit risk ratio is which a quotient of non-performing loans to total assets and indicates the proportion of non-performing loans to total

$\mathbf{a}=$ constant term of the model

$\boldsymbol{\beta}_{\mathbf{i}}=$ coefficients of the model, $\mathrm{i}=1,2,3,4,5$.

$\varepsilon=$ error term

\section{Results and Discussion.}

Bank performance

The research involved panel data for banks across a five-year period. Financial ratios were used for comparison across the multiple years. The Return on Assets (ROA) was used as the performance measures, consistent with the research objectives. Table 1 summarizes the profitability of banks.

Table 1: Overall Bank Profitability

\begin{tabular}{|l|r|r|r|r|r|r|}
\hline & \multicolumn{1}{|c|}{2013} & \multicolumn{1}{c|}{2014} & \multicolumn{1}{c|}{2015} & \multicolumn{1}{c|}{2016} & \multicolumn{1}{c|}{2017} & Average \\
\hline $\mathrm{N}$ & 36 & 36 & 36 & 36 & 36 & 36 \\
Mean & $3.7 \%$ & $3.0 \%$ & $2.2 \%$ & $1.9 \%$ & $1.2 \%$ & $2.4 \%$ \\
Std. Deviation & $4.9 \%$ & $2.9 \%$ & $2.7 \%$ & $3.1 \%$ & $3.8 \%$ & $3.5 \%$ \\
Range & $37.0 \%$ & $16.0 \%$ & $11.0 \%$ & $14.0 \%$ & $21.0 \%$ & $20.0 \%$ \\
Minimum & $-7.0 \%$ & $-7.0 \%$ & $-5.0 \%$ & $-7.0 \%$ & $-14.0 \%$ & $-8.0 \%$ \\
Maximum & $30.0 \%$ & $9.0 \%$ & $7.0 \%$ & $7.0 \%$ & $7.0 \%$ & $12.0 \%$ \\
\hline
\end{tabular}

The above analyses indicate the impact of firm-specific characteristics on profitability indicated by the ROA. During the period of study, commercial banks performed at an average of $2.4 \%$. The highest mean was reported in 2013 with a mean of $3.7 \%$ while lowest return was in 2017 which recorded a mean ROA of $1.2 \%$. This indicates a decline in return with each year, indicating a worsening profitability level for the banking industry. Fluctuations on ROA during the period of study were averaged at 3.5\%. 2013 recorded the highest standard deviation of $4.9 \%$ while 2015 recorded the lowest deviation of $2.7 \%$. The minimum return on asset was recorded in 2015 at $-5.0 \%$ while the maximum returns was recorded in 2013 at $30.0 \%$. 
Figure 2: ROA Trend Analysis

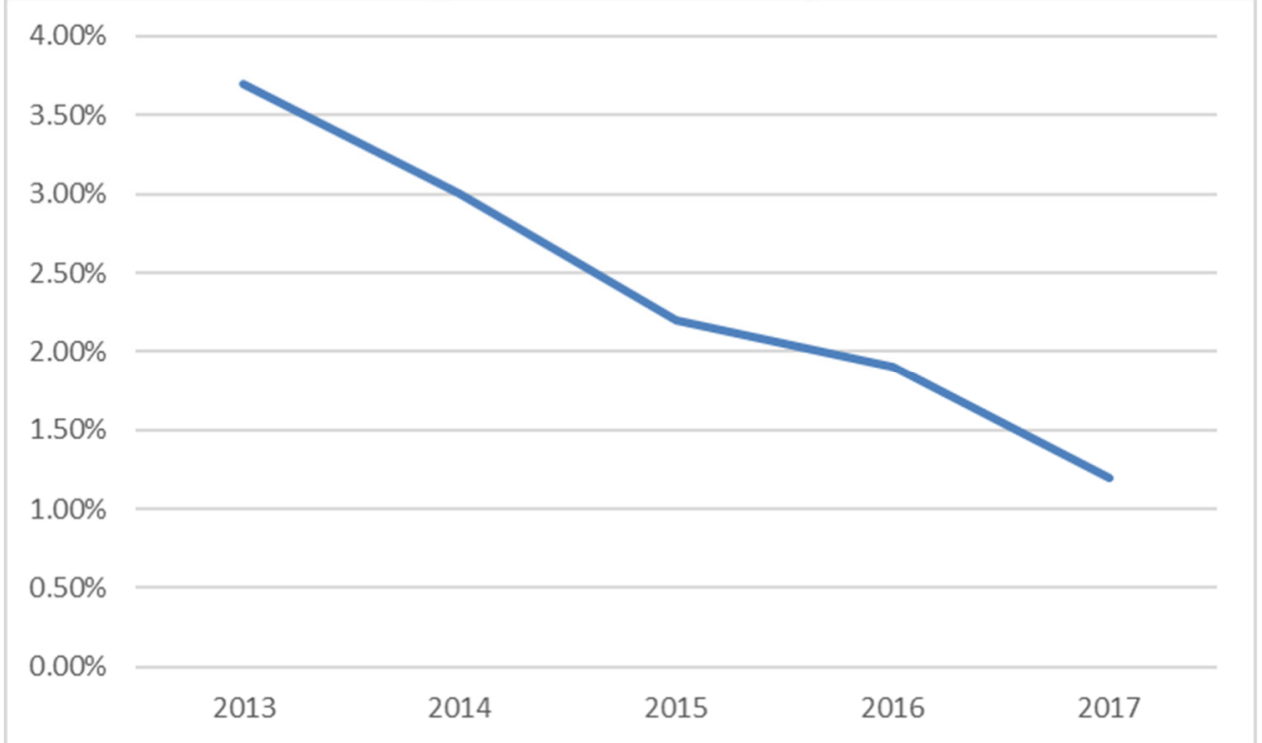

The mean ROA in 2013 was 3.66 percent, the highest for the period. The return measure declined with each year, indicating a worsening profitability level for the banking industry. However, the high standard deviation, high range between the maximum and minimum ROA suggest the impact of firm-specific characteristics on profitability indicated by the ROA.

Majority of banks recorded their highest returns in 2013.The ROA declined steadily to reach the lowest ratio across the period of 1.2 percent.

\section{Capital Adequacy}

Table 2: Overall Capital Adequacy

\begin{tabular}{|l|l|l|l|l|l|}
\hline & $\mathrm{N}$ & Minimum & Maximum & Mean & Std. Deviation \\
\hline 2013 & 36 & $11.0 \%$ & $153.0 \%$ & $28.3 \%$ & $22.0 \%$ \\
2014 & 36 & $0.0 \%$ & $100.0 \%$ & $23.0 \%$ & $9.9 \%$ \\
2015 & 36 & $9.0 \%$ & $73.0 \%$ & $22.2 \%$ & $11.7 \%$ \\
2016 & 36 & $2.0 \%$ & $49.0 \%$ & $23.9 \%$ & $9.7 \%$ \\
2017 & 36 & $9.0 \%$ & $125.0 \%$ & $27.7 \%$ & $20.6 \%$ \\
Average & $\mathbf{3 6}$ & $\mathbf{6 . 2 \%}$ & $\mathbf{1 0 0 . 0} \%$ & $\mathbf{2 5 . 0 \%}$ & $\mathbf{1 4 . 8 \%}$ \\
\hline
\end{tabular}

From the above table, the average capital adequacy for the period under review was $25.0 \%$.

The average capital adequacy ratio remained relatively stable across the years, with the regulation seemingly resulting in a decline in the capital adequacy ratio. Banks appeared to adjust their capital position in 2014 and maintained that ratio to 2016. However, the average capital adequacy increased to a level comparable to that observed in 2017.

Figure 3: Capital adequacy Trend Analysis

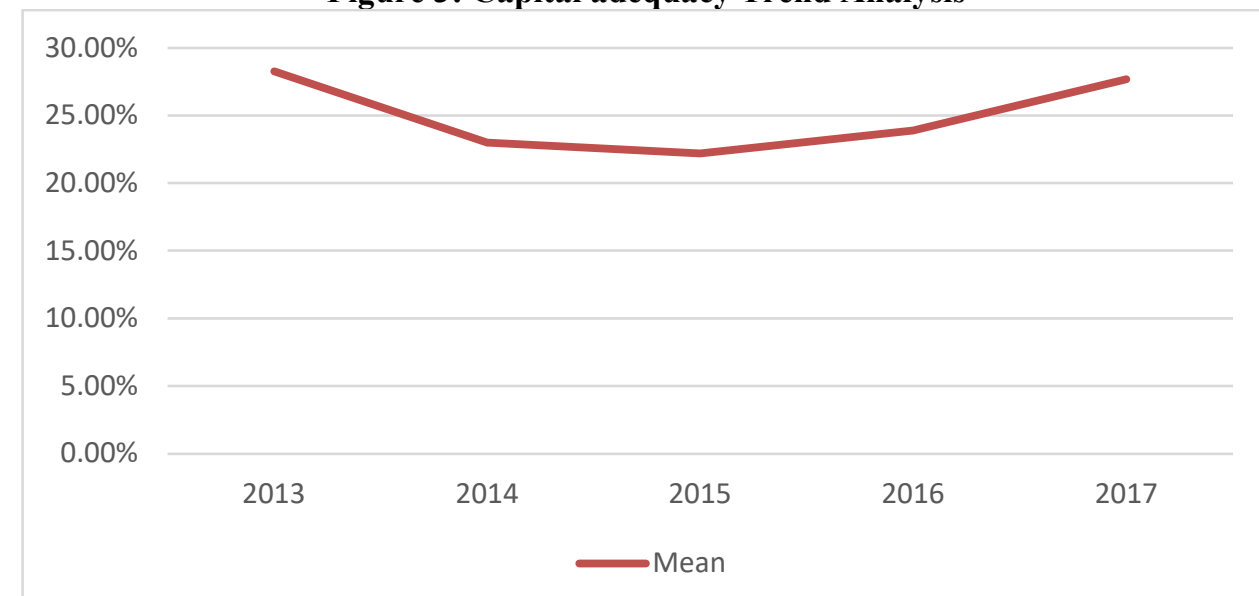

The Capital Adequacy ratio maintained a more level position, with the average ratio fluctuating between 22.2 percent and 28.3 percent over the study period. After regulation, the ratio declined from the high of 28.3 percent 
to 22.2 percent in 2015 , followed by increase in capital adequacy in the next two years to get back to 27.7 percent in 2017. Banks had some movement in capital adequacy that reduced capital adequacy levels, but reverted back to initial capital levels by the end of the period. Based on the trend analysis, banks on average hold $0.22-0.28$ in capital for every held in risk-weighted assets.

\section{Liquidity Management}

Table 3. Overall Liquidity Ratio

\begin{tabular}{|r|r|r|r|r|}
\hline & Minimum & Maximum & Mean & \multicolumn{1}{c|}{ Std. Deviation } \\
\hline 2013 & $48.0 \%$ & $491.0 \%$ & $83.2 \%$ & $65.2 \%$ \\
2014 & $0.0 \%$ & $100.0 \%$ & $68.0 \%$ & $19.5 \%$ \\
2015 & $7.0 \%$ & $748.0 \%$ & $86.6 \%$ & $108.2 \%$ \\
2016 & $35.0 \%$ & $85.0 \%$ & $68.7 \%$ & $11.4 \%$ \\
2017 & $44.0 \%$ & $92.0 \%$ & $73.5 \%$ & $10.0 \%$ \\
Average & $\mathbf{2 6 . 8 \%}$ & $\mathbf{3 0 3 . 2 \%}$ & $\mathbf{7 6 . 0 \%}$ & $\mathbf{4 2 . 9 \%}$ \\
\hline
\end{tabular}

The average mean liquidity for banks during the period of study was 76.0 percent. Liquidity ratio trend shown in figure 4 points to disparities in liquidity positions. The highest liquidity ratio was observed in 2013 with a mean of 83.20 percent. While the lowest was recorded in 2014 at 68.0 percent. Standard deviation was averaged at 42.9 percent. 2015 recorded the highest standard deviation of 108.2 percent while 2017 recorded the lowest standard deviation of 1.0 percent. The average maximum liquidity was 303.2 percent while the average minimum was 26.8 percent.

Figure 4: Overall liquidity Trend Analysis

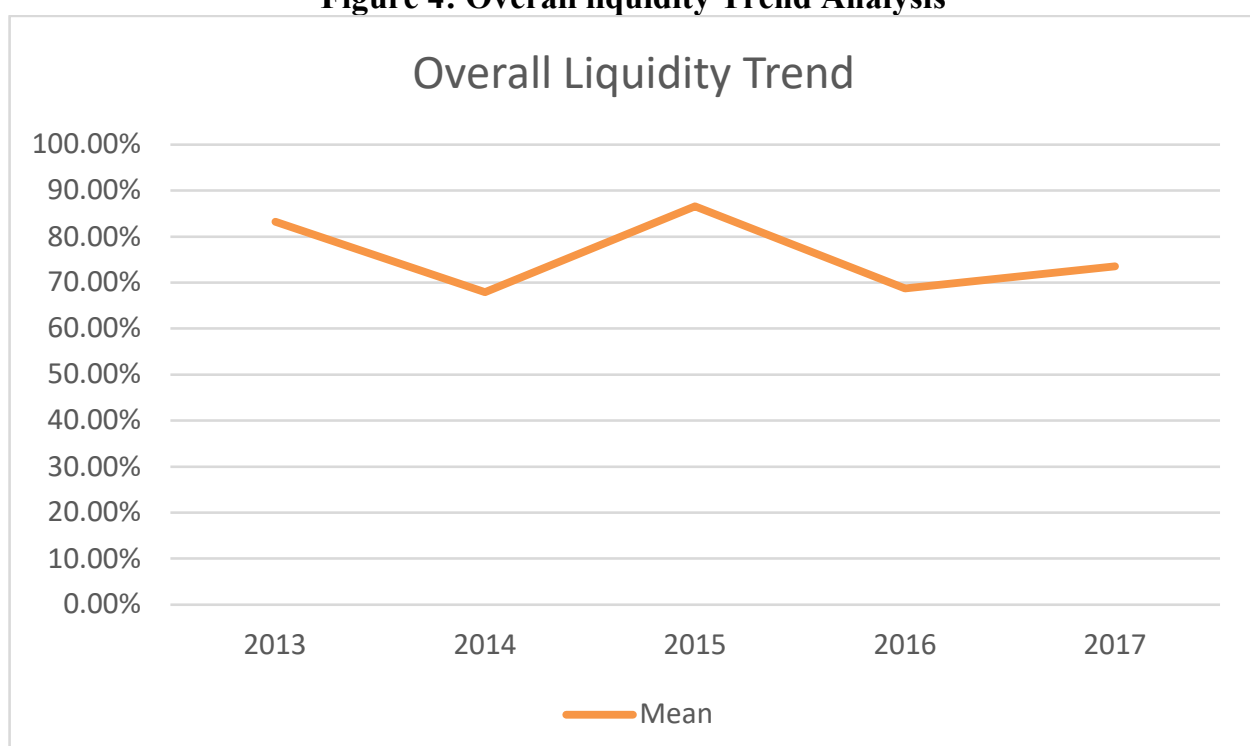

The liquidity trend shows stability in the liquidity. The liquidity ratio was highest in 2013 , with the year's average at 83.2 percent. The ratio decreased to 68 percent, but increased to 86.6 percent in 2015 . After 2015, average liquidity reverted back to the 68 percent mark in 2016 before increasing to 73.5 percent in the last year. Banks appear to maintain a high liquidity ratio, but once that ensures deposits are completely covered by held assets.

\section{Asset Quality}

Table 4: Overall Asset Quality Ratio Statistics

\begin{tabular}{|c|c|c|c|c|}
\hline & Minimum & Maximum & Mean & Std. Deviation \\
\hline 2013 & 0 & 0.19 & 0.0636 & 0.05206 \\
\hline 2014 & 0 & 1 & 0.0800 & 0.09900 \\
\hline 2015 & 0 & 0.33 & 0.1077 & 0.08557 \\
\hline 2016 & 0 & 1.06 & 0.1661 & 0.22998 \\
\hline 2017 & 0 & 2.59 & 0.2861 & 0.46296 \\
\hline Average & & 1.034 & 0.1407 & 0.18591 \\
\hline
\end{tabular}

The average mean asset quality for banks during the period of study was 0.14 . Asset quality trend shown in Table 4 points to disparities in asset quality. The highest ratio was observed in 2017 with a mean of 0.28 percent. While the lowest was recorded in 2013 at 0.63 .

Standard deviation was average at 0.18 . The year 2017 recorded the highest standard deviation of 0.46 while 
2013 recorded the lowest standard deviation of 0.05 . The average maximum asset quality was 1.03 while the average minimum was 0.14 .

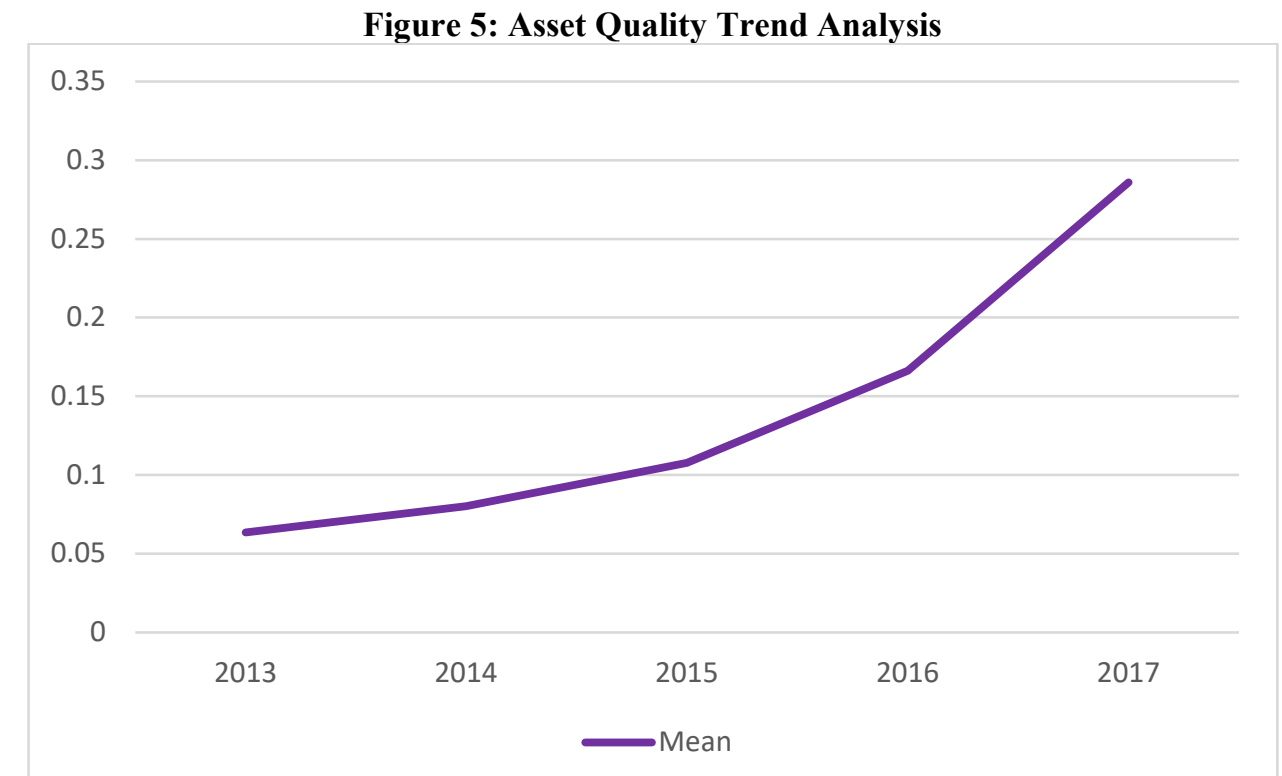

The asset quality ratio has been on an exponential growth from 2013 to 2017 , rising from 6.36 percent to 28.6 percent. The first two years had gradual growth where the ratio increased to 10.77 percent. After 2015, the ratio grew exponentially, first to 16.6 percent in 2016 and then to 28.6 percent in 2017 . The high growth in the ratio is worrying since it indicates weakening credit management policies.

\section{Management Efficiency}

Table 5: Overall Management Efficiency

\begin{tabular}{|r|r|r|r|r|}
\hline & Minimum & Maximum & Mean & Std. Deviation \\
\hline 2013 & $25.0 \%$ & $175.0 \%$ & $63.5 \%$ & $25.5 \%$ \\
2014 & $0.0 \%$ & $100.0 \%$ & $65.0 \%$ & $21.3 \%$ \\
2015 & $5.0 \%$ & $182.0 \%$ & $66.3 \%$ & $32.9 \%$ \\
2016 & $28.0 \%$ & $324.0 \%$ & $82.6 \%$ & $58.5 \%$ \\
2017 & $28.0 \%$ & $387.0 \%$ & $90.4 \%$ & $67.6 \%$ \\
Average & $\mathbf{1 7 . 2 \%}$ & $\mathbf{2 3 3 . 6 \%}$ & $\mathbf{7 3 . 6 \%}$ & $\mathbf{4 1 . 2 \%}$ \\
\hline
\end{tabular}

The management efficiency for banks kept declining with each year, with 2013 being the most efficient where operating expenses were 63.52 percent of revenues. This increased marginally in 2014 and 2015 to 65.00 percent and 66.30 percent respectively. 2016 represented a difficult year for the industry, with majority of banks unable to control expenses, which saw the management efficiency ratio increase to 82.55 percent of revenues. The position worsened even further in 2017 , where the average ratio was 0.90 percent.

Figure 6: Management Efficiency Trend

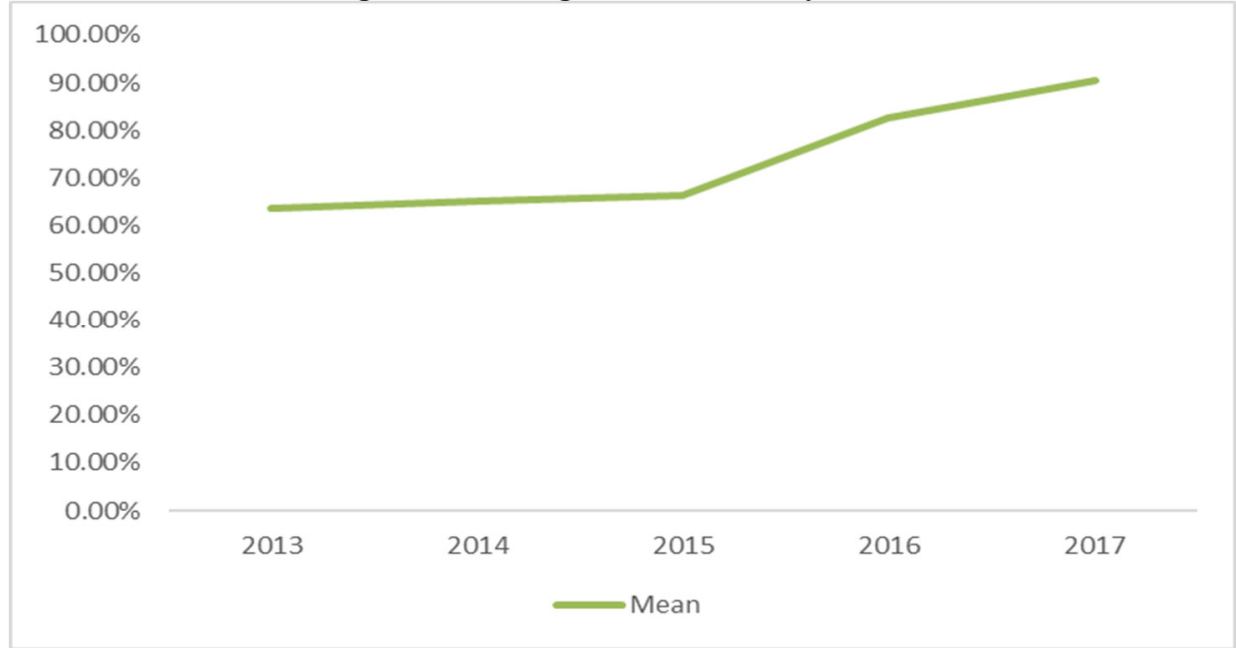




\section{Analysis}

The management efficiency ratio increased from an average of 63.5 percent in 2013 to an average of 90.40 percent in 2017 as shown in figure 6. Up until 2015, the ratio was stable, increasing to 66.3 percent. However, the management efficiency ratio increased drastically in 2016 to an average of 82.6 percent. By 2017, the average management efficiency ratio was 90.4 percent. The increase in management efficiency ratio indicates weak cost management structures across the industry.

Credit Risk management

Table 6: Overall Credit Risk

\begin{tabular}{|r|r|r|r|r|}
\hline & Minimum & Maximum & Mean & \multicolumn{1}{|c|}{ Std. Deviation } \\
\hline 2013 & 0 & 0.4 & 0.0385 & 0.06482 \\
2014 & 0 & 1 & 0.0600 & 0.106 \\
2015 & 0 & 0.88 & 0.0846 & 0.14298 \\
2016 & 0 & 0.26 & 0.0696 & 0.06093 \\
2017 & 0 & 0.28 & 0.0993 & 0.0857 \\
Average & $\mathbf{0}$ & $\mathbf{0 . 5 6 4}$ & $\mathbf{0 . 0 7 0 4}$ & $\mathbf{0 . 0 9 2 0 9}$ \\
\hline
\end{tabular}

The credit risk management ratio was in 2013 was 0.0385 , indicating low industry risk as non-performing loans were equal to 3.85 percent of total assets. The ratio increased over the years, with the average n 2017 at 0.099; the proportion of non-performing loans for the average industry stood at 9.9 percent of total firm assets.

Figure 7: Credit Risk Management trend analysis

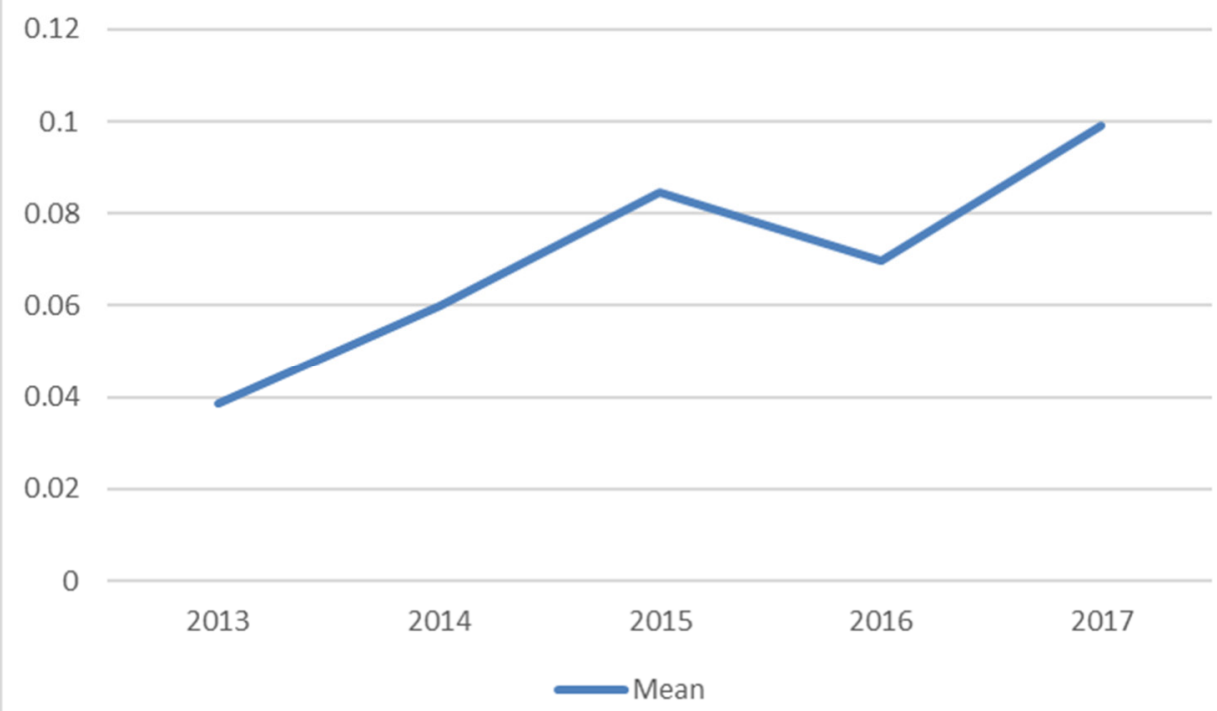

The credit risk management ratio trend is an upward curve as illustrated in figure 7, with banks increasing their loan portfolios without proportionate increase in assets. The ratio was at its lowest in 2013, where the average credit risk ratio was 0.0385 . This was followed by a sharp increase in 2014 and 2015, taking it to an average of 0.0846. There was a sharp decline in the CR ratio in 2016 that brought it down to 0.0696 , but this was reversed in 2017 to take the average ratio to 0.0993 , the highest ratio across the five-year period. Consequently, banks appear to be struggling to manage growing loan portfolios

\section{Inferential Statistics}

\section{Multi-collinearity Test}

For multiple regressions to be effective, variables need to be independent to ensure that the variables improve the prediction model. Multi-collinearity is a term used to explain correlation that exists between independent variables in a linear relationship. Multi-collinearity is measured using the Variance Inflation Factor (VIF) and the Tolerance Value. When the VIF is too high or too low, there is multi-collinearity. Specifically, when the VIF is zero of less, there is multi-collinearity among the variables. Similarly, when the VIF is greater than 10, there is multicollinearity in the variables. A regression model is only effective when any multi-collinearity among the variables is removed by identifying and eliminating related variables using the VIF factor (Meyers et al., 2016). 
Table 7: Collinearity Diagnostics

\begin{tabular}{|l|r|r|}
\hline Model & \multicolumn{2}{|c|}{ Collinearity Statistics } \\
\cline { 2 - 3 } & Tolerance & VIF \\
\cline { 2 - 3 } Capital Adequacy & .720 & 1.390 \\
Liquidity & .763 & 1.311 \\
Asset Quality & .595 & 1.679 \\
Management efficiency & .818 & 1.223 \\
Credit risk & .561 & 1.782 \\
\hline
\end{tabular}

Using ROA as the dependent variable and the five independent variables, all the VIFs fall above 0.1 and are less than 10, making them all within the acceptable range for the absence of multi -collinearity. The VIF and tolerance values indicate that there is no existence of multicollinearity among the independent variables.

\section{Correlation Matrix}

The correlation coefficient is a measure of the strength and direction of the linear relationship between two variables. The coefficient ranges from -1 to 1 , with -1 indicating a perfect negative linear relationship and 1 indicating a perfect positive linear relationship between the variables (Meyers et al., 2016).

Table 8: Correlation Matrix

\begin{tabular}{|c|c|c|c|c|c|c|}
\hline & ROA & L.M & $\mathrm{CA}$ & $\mathrm{AQ}$ & $\mathrm{ME}$ & $\mathrm{CR}$ \\
\hline $\mathrm{ROA}$ & 1 & & & & & \\
\hline LM & 0.174423 & 1 & & & & \\
\hline $\mathrm{CA}$ & -0.03577 & 0.231219 & 1 & & & \\
\hline $\mathrm{AQ}$ & -0.31545 & -0.14862 & -0.09582 & 1 & & \\
\hline $\mathrm{ME}$ & 0.096552 & -0.24437 & -0.34475 & 0.243233 & 1 & \\
\hline CR & -0.41675 & 0.179479 & 0.046452 & 0.610061 & 0.258556 & 1 \\
\hline
\end{tabular}

According to the analysis, out of the five independent variables, liquidity ratio has the strongest positive relationship with ROA, with a correlation value of 0.174 . Alternatively; credit risk has the strongest negative relationship with ROA at -0.42 , indicating weak negative linear relationships with performance measures. Asset quality has a weak negative correlation with ROA $(\mathrm{r}=-0.31)$ whereas capital adequacy has no linear relationship with the dependent variable $(\mathrm{r}=-0.03)$.

\section{Regression Analysis}

The multiple regression model allows for the prediction of linear relationship that exists between the dependent variable and more than one predictor variable. The researcher considered the five predictors of the variables that determine firm performance. This section will display the output of the multiple regression models for the multiple years and discuss findings and make inferences in line with hypothesis.

The regression model fitted using the average panel data and the model summary provided in Table 9.

Table 9: Regression Model Summary

\begin{tabular}{|c|c|c|c|c|c|}
\hline Model & $\mathrm{R}$ & R Square & Adjusted R Square & Std. Error of the Estimate & Durbin-Watson \\
\hline 1 & $.594^{\mathrm{a}}$ & .353 & .263 & .0236667 & 2.153 \\
\hline
\end{tabular}

Table 10: ANOVA

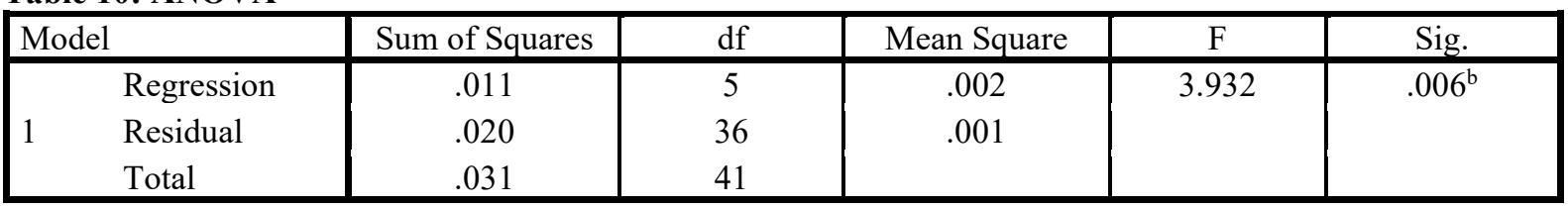


Table 11:Coefficients ${ }^{\mathrm{b}}$

\begin{tabular}{|l|c|c|c|c|c|}
\hline \multirow{2}{*}{ Model } & \multicolumn{2}{|c|}{ Unstandardized Coefficients } & Standardized Coefficients & \multirow{2}{*}{ Sig. } \\
\cline { 2 - 5 } & $\mathrm{B}$ & Std. Error & Beta & & \\
\hline (Constant) & -.013 & .020 & & -.642 & .525 \\
$\mathrm{CA}$ & .013 & .041 & .048 & .324 & .748 \\
$\mathrm{LM}$ & .038 & .015 & .376 & 2.464 & .019 \\
$\mathrm{AQ}$ & .017 & .037 & .084 & .460 & .648 \\
$\mathrm{CR}$ & -.267 & .080 & -.654 & -3.332 & .002 \\
$\mathrm{ME}$ & .031 & .013 & .389 & 2.470 & .018 \\
\hline
\end{tabular}

a. Predictors: (Constant), CA, LM, AQ, CR, ME.

b. Dependent Variable: ROA

From the model summary in table 9 , the $\mathrm{R}$ is 0.594 . The model has an $\mathrm{R}^{2}$ (coefficient of determination) of 0.353 , which means that the predictor variables explains for $35.3 \%$ of the variation in the ROA. The rest is explained by factors not concerned in this study.

In table 10, ANOVA was used to establish the significance of the regression model used in the study. The $\mathrm{F}$ value was 3.932 and its significance level is at 0.006 indicating that the independent variables are significant in predicting the financial performance of commercial banks in Kenya at 95\% significance level. The ANOVA analysis also indicate that there is significant difference in the groups $(F=3.93, p=0.006)$, validating inclusion five variables in the regression equation.

From the above regression model, holding capital adequacy, liquidity management, asset quality, credit risk management and management efficiency constant, financial performance of the commercial banks would be achieved at a unit of -.013. It was also established that a unit increase in capital adequacy would cause an increase in financial performance by a factor of 0.013 , a unit increase in liquidity management would result in an increase in financial performance of the commercial banks by a factor of 0.038 , a unit increase in asset quality would result in an increase in financial performance of the commercial banks by a factor of 0.017 , a unit increase in credit risk management would cause a decrease of financial performance of the commercial banks by a factor of 0.267 , a unit increase in management efficiency would result in an increase in financial performance of the commercial banks by a factor of 0.031 .

The decision factor in the test is that if $\mathrm{P}$ value observed is less than the set alpha at the confidence level of 0.05 , then the null hypothesis is rejected and the alternative hypothesis is accepted. If the if $\mathrm{P}$ value observed is greater than the set alpha at the confidence level of 0.05 , then the null hypothesis is accepted.

$\mathbf{H}_{01}$ : Capital adequacy regulation has no significant effect on profitability of commercial banks.

The first research objective was achieved by evaluating the null hypothesis that capital adequacy regulation has no significant effect on profitability of commercial banks. This was evaluated using the regression results from the overall regression model in table 11. From the regression model, the beta coefficient is 0.013 with a p-value of 0.748 , which is higher than the critical p-value of 0.05 . Based on t-test, the study failed to reject the null hypothesis thus capital adequacy regulation has no significant effect on profitability of commercial banks. The study findings is consistent with research finding carried out by Molefe \& Muzindutsi (2016), Nyanga (2012) and Karanja \& Nasieku (2016), the capital adequacy declined between 2013 and 2017.

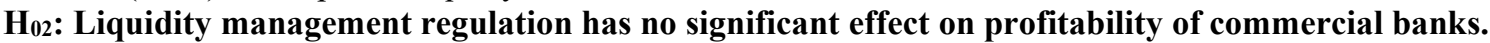

This research objective was achieved by testing the null hypothesis that liquidity management regulation had no significant effect on profitability. The hypothesis was tested using the regression output in table 11 . From the regression, the beta is 0.038 , and has a p-value of 0.019 , which is less than the critical $p$-value of 0.05 . Therefore, based on the t-test results, the null hypothesis was rejected and the alternative was accepted. Therefore liquidity management regulation has significant effect on the profitability of commercial banks.. The study findings concur with the findings of the research made by Ondieki \& Nyakundi (2013), which indicated liquidity management improved profitability of banks.

Ho3: Asset quality regulation has no significant effect on profitability of commercial banks.

The third research objective was achieved by testing the null hypothesis that asset quality regulation had no effect on profitability of commercial banks. From the regression model output based in table 11, Asset quality has a beta coefficient of 0.017 , with a p-value of 0.648 which is higher than the critical p-value of 0.05 . Consequently, the study failed to reject the null hypothesis thus asset quality regulation had no significant impact on profitability of banks. The research findings made differed with conclusions made from the research carried out by Ondieki \& Nyakundi (2013) and Nzoka (2015), who observed that improved asset quality increased profitability of commercial banks.

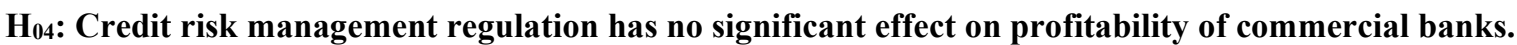
The fourth objective was achieved by testing the null hypothesis that there is no significant relationship between 
credit risk management regulation and profitability. From the multiple regression model in table 11 , the beta coefficient for Credit Risk is -0.267 at a p-value of 0.002 which is less than the critical p-value of 0.05 . In this case, the null hypothesis is rejected in favor of the alternate that the variable has a significant effect. Credit risk management has statistically significant impact on the profitability of commercial banks. Credit risk ratio is negatively related to performance. This research findings is consistent with the research findings made by Kimotho (2015) and Mwangi (2014) that credit risk regulations improved bank stability and performance.

$H_{05}$ : Management efficiency regulation has no significant effect on profitability of commercial banks.

The fifth objective was achieved by testing the null hypothesis that there is no significant relationship between management efficient regulation and profitability of commercial banks. From the regression results in table 11, the beta coefficient is 0.031 at a p-value of 0.018 which is less than the critical $p$-value of 0.05 consequently, the null hypothesis is rejected and the alternative hypothesis is accepted. Management efficiency has statistically significant impact on the profitability of commercial banks. Management efficiency ratio has a positive relationship with performance, with increasing cost as a result of ineffective cost management negatively impacting financial performance. The research findings support the conclusions made in a research done by Njuele, (2013) and Ochieng (2014).

\section{Conclusions}

The study considered a trend analysis to determine the impact of capital adequacy and concluded that the regulation led reduction in capital adequacy. Banks maintained low capital adequacy ratios throughout the period, holding significantly higher proportions of risk weighted assets to shareholder's equity. Smaller banks had the higher capital adequacy ratios compared to larger banks that utilize debt capital to acquire assets.

Banks in the industry struggled with liquidity, especially smaller banks that over-relied on deposits to operate. This indicates that banks in the small peer group operate with low capital levels. Assuming that regulations are set when banks are licensed to ensure capital levels are maintained, the high demand for banking services creates abnormal growth trajectories for banks as they attract customer deposits faster than their capital growth. From the regression model, liquidity has a positive linear relationship with bank performance based on the performance measure.

Asset quality ratio has a negative linear relationship with performance and based on beta coefficients is the most significant predictor of performance and credit risk the second most significant variable in the model. A unit increase in asset quality resulted in an increase in financial performance of the commercial banks by a factor of 0.017 . The asset quality trend indicates a general increase in the asset quality ratio, an indication of the increase in the proportion of non-performing loans issued by banks in the financial sector.

The study findings indicated management efficiency as having significant effect on performance. Management efficiency ratio has a positive relationship with performance, the ratio kept declining over the years with increasing cost as a result of ineffective cost management negatively impacting financial performance.

Credit risk management regulation also had a significant impact on performance with credit risk ratio negatively related to performance. From the research findings, the credit management ratio trend was upward over the study period indicating that non-performing loans in banks were on the rise. This affected performance negatively.

\section{Recommendation}

Based on the inferences made under conclusions, the researcher proposes the following recommendations to stakeholders. The recommendations are influenced by the current study's findings based on the descriptive statistics and regression models in the report.

Prudential regulations have affected how bank's commitment to maintain CBK capital levels. This has meant raising more capital from shareholders and reinvesting back realized profits to achieve the regulator's capital guidelines for banks. It is recommended that banks, especially small and medium banks develop strategies to raise their capital levels to adequate levels to lower risk of solvency.

It is advisable that banks recruit effective management teams and develop stronger internal controls to improve efficiency and credit risk levels. Over the period, banks have struggled to contain escalating costs that have reduced their profit levels. Unchecked costs result in losses, which reduce capital. It is factual that changes in the macro-economic environment may have contributed to the situation, but larger banks were less affected than small and medium banks.

Banks should lower their non-performing portfolios to secure their long-term stability. The current credit risk is extremely high at between 8 and 12 percent of total assets. Banks should strengthen their internal controls and credit policies to secure their survival.

The regulator (CBK) should ensure all banks operating in Kenya adopt the prudential regulation as it ensures that banks have adequate capital. Liquidity problems arise as a direct consequence of low capital input, which force inadequately financed banks to rely on deposits for working capital. Significant withdrawal of deposits ends 
up crippling banks, a scenario observed through banks that have become insolvent in this period.

The regulator should seek to provide more holistic and integrated regulations to avoid stifling the industry like during this period where bank performance continued to decline. Regulatory policy should create stability without shrinking the industry.

\section{Suggestion for Further Studies}

Scholars can investigate intervening variables to the relationship between performance and the five predicting variables in this study, which can improve even further the model's predictive accuracy. The study identified credit risk and management efficiency as the only significant predictors of profitability. The study can be improved by identifying other regulatory factors that affect profitability from the prudential performance, which include using other accounting measures that may be more appropriate for indicating capital adequacy, liquidity and asset quality.

The study also used accounting measure of ROA to measure performance. This is a subjective performance measures that could be manipulated by the firms and may not reflect the true measure of financial performance. Another study can be conducted using different performance measures with the same variables.

\section{References}

Ali, A.E. (2015). The Regulatory and Supervision Framework of Microfinance in Kenya. International Journal of Social Sciences and Studies, 3(5), 1-9.

Alamayehu, G. \& Ndung'u, N. (2012), Applied Time Series Econometrics: A Practical Guide for Macroeconomic Researchers with a Focus on Africa, UON.

Anguka W. (2012). The Influence of Financial Risk Management on the Financial Performance of Commercial Banks in Kenya. International Journal of Financial Economics, 5(1), 1-71.

Athanasoglou, P.P., Sophocles, N.B., \& Matthaios, D.D. (2005) Bank-specific, industry-specific and macroeconomic determinants of bank profitability. International journal of advanced research 1(1), 3-4.

Beltratti, A., \&Stulz, R. M. (2012). The credit crisis around the globe: Why did some banks perform better?International Journal of Financial Economics, 105(1), 1-17.

Calem, P.S., \& Rob, R. (1996). The Impact of Capital-Based Regulation on Bank Risk taking. A Dynamic Model, Board of Governors of the Federal Reserve System.Finance and Economics Discussion Series 96(12), 36-41.

Central Bank of Kenya (2014).Bank Supervision Annual Report 2013. Central Bank of Kenya supervision report. Retrieved from http://www.centralbank.go.ke

Central Bank of Kenya (2015).Bank Supervision Annual Report 2014. Central Bank of Kenya supervision report. Retrieved from http://www.centralbank.go.ke.

Claessens, S., \&Horen, N. (2014). Foreign banks: Trends and impact. Journal of Money, Credit and Banking, 46(1), 295-326.

Eden, K. (2014). The impact of national bank of Ethiopia regulation on bank performance. International Business Research, 2(1).

Geda. A.,\& Ndung'u, N. (2012).Applied Time Series Econometrics: A Practical Guide for Macroeconomic Researchers with a Focus on Africa.Nairobi: University of Nairobi Press, UONP.

Gorowa,S.U., \& Igyo, A. J. (2017). Effect of Corporate Governance on Asset Quality: Performance Evaluation of the Nigerian Banking Sector in the Post Consolidation Era. International Journal of Accounting, Finance and Risk Management. 2(1),1-9.

Gudmundsson, R., Ngoka-Kisinguh, K.,\& Odongo, M.T. (2013). The Role of Capital Requirements on Bank Competition and Stability: The Case of the Kenyan Banking Industry. Kenya Bankers Association-KBA Centre for Research on Financial Markets and Policy Working Paper Series.

Guthua, A. M. (2013). Effects of asset liability management on the liquidity of commercial banks in Kenya. Journal of Accounting, Finance 1(3).1-53

Jansen, E. (1997). Self-Efficacy and Venture Performance: A Longitudinal Study. International journal of Management Proceedings.

Karanja, J. S., \& Nasieku, T. (2016). Effect of Capital on the Financial Performance of Commercial Banks in Kenya. Asian Journal of Business and Management, 4(5), 221-238.

Kimotho D. N. (2015). Effects of Credit Risk Management Practices on Financial Performance of Commercial banks in Kenya International Journal of Business, Social Sciences and Education. 1(2) 3-15

Kipruto J. J.,Osodo O. P., \& Wepukhulu J.M. (2017). The influence of capital adequacy ratio on the financial performance of Commercial banks in Kenya. International journal of

Laeven, L., \& Levine, R. (2009). Bank governance, regulation and risk taking. Journal of Financial Economics, 93(2), 259-275.

Mabeya K.O., Nyakundi A.W., \& Abuga M. V. (2016) Effects implementation of the Central bank of Kenya prudential guidelines on profitability of Commercial banks in Kenya.International journal of Social sciences and Information technology, 2(3), 1-23. 
Majakusi, J. (2016). Effect of Liquidity management on the financial performance of commercial banks in Kenya.Journal of Business and management 9-45.

Masinde, K., (2017). Effects of Credit Risk on the Financial performance of commercial banks in Kenya. Journal of Finance and Accounting 1(3)7-43.

Molefe B, \& Muzindutsi (2016) The effect of capital and liquidity management on Profitability of major South African Banks. Basel II requirement on Kenyan Commercial Banks’ lending. Journal of Finance and Bank Management, 1-8.

Mwangi Y.K. (2014). The effect of risk management on financial performance of commercial banks in Kenya.Journal of Social sciences and Economics, 12(I)

Mwega, F. M. (2014). Financial regulation in Kenya: balancing inclusive growth with financial .

Mwongeli A. J. (2016). The effect of regulation on the financial performance of commercial banks in Kenya. Journal of Financial Economics, 2(1) 5-56

Ndolo, A. (2017). The effects of Central bank of Kenya regulations on the financial performance of commercial banks listed in Nairobi security exchange in Kenya. Economics and finance reviewjournal, 1(1), 1-39

Njeule M. A. (2013). The effect of Central bank of Kenya prudential regulation on financial performance Commercial Banks in Kenya. Journal of Financial economics. 2(1),9-15.

Nyanga, O. (2012). Determinants of financial performance of commercial banks in Kenya. Journal of Business research, 22, 1-9.

Nzioki,J.S. (2011). Impact of capital adequacy on the financial performance of commercial banks quoted at the Nairobi stock exchange. Journal of economics, finance and banking, 2(4), 3-17.

Nzoka, F. K (2015). The effects of assets quality on the financial performance of commercial Banks in Kenya. Journal of bankingand finance 1(1), 10-71

Ochieng, J.O. (2014). The effect of Central bank of Kenya prudential guidelines and regulations on the financial performance of commercial banks in Kenya.International Journal of bankingand finance 5(2), 1-22

Odongo, F. O. (2013). Stock price reaction to changes in capital adequacy regulation in the Kenyan banking sector. Journal of Accountingand economicsII(1).

Ondieki, D. N., \&Nyakundi, A. (2013). Effects of lowering central bank rate on bank's prime rate: An analysis of Kenyan commercial banks. Journal of finance and banking management, 1(2), 1-8.

Ongore, V. O., \& Kusa, G. B. (2013). Determinants of financial performance of commercial banks in Kenya. International journal of economics and financial issues, 3(1), 237-252.

Sentero D.R. (2013). The effect of capital adequacy regulation on efficiency of commercial banks in Kenya.International Journal of bankingissues 19(1), 1-108.

Wanjohi1, S.M,\&. (2017). The effect of financial risk management on the financial performance of commercial banks in Kenya.International journal of finance and banking Research. 